\title{
LANDSCAPE AND ITS FUNCTIONS IN THE STORIES OF “CHRISTMAS TREE” BY MYKHAILO KOTSIUBYNSKYI AND “PINE TREE" BY OLENA PCHILKA
}

\author{
NATALIIA VIVCHARYK
}

\begin{abstract}
The article proves that the implementation of a comprehensive approach to the aesthetic education of students in NUS involves, along with the traditional teaching of subjects, their integration, in particular in the humanitarian, artistic cycle. "The concept of artistic and aesthetic education of students in secondary schools" indicates the need to take into account interdisciplinary, intersectoral links within modern school education because educational processes provide rational, aesthetic, and emotional understanding of the phenomena of the surrounding reality. The article points out that the concept of landscape is interdisciplinary and is used in various fields of art, including literature, which influences the formation of personality, helps gain some knowledge about the environment, the relationship between people and nature. The article analyzes the functions of landscapes in children's stories "Christmas Tree" by Mykhailo Kotsiubynskyi and "Pine Tree" by Olena Pchilka in detail. Attention is paid to the consonance of the names of works of art. It is proved that titles implicitly outline the time of action and are projected on the plot. The creative style of Olena Pchilka and Mykhailo Kotsiubynskyi is characterized by the "revival" of nature. On the background of winter landscapes, the writers depict the lives of different segments of the population, customs and traditions associated with Christmas. It is indicated that landscapes perform both pictorial and characterological functions. Describing the preparation for Christmas, the writers appeal to the use of contrasts, which helps reveal social issues. In both works, the symbolic marker of wealth/poverty is a Christmas tree/pine tree. Descriptions of the winter elements evoke tragic premonitions. The emotionality of the story emphasizes the rupture of phrases, the accumulation of exclamatory and interrogative constructions. It is shown that landscapes convey the inner experiences of the characters, who successfully overcome all the difficulties and return home. By resorting to the synthesis of arts, using visual materials and musical accompaniment, teachers can develop students' associative thinking and teach to comprehensively analyze information. Analyzing the stories "Christmas Tree" by Mykhailo Kotsiubynskyi and "Pine Tree" by Olena Pchilka, students consider not only the topics and issues, but also comprehend the processes of human interaction with nature, which serves to form a humane attitude to the environment and develops aesthetic feelings.
\end{abstract}

Keywords: education, students, integration, synthesis of arts, fiction, landscape, story, title, image, detail, landscape, contrast, symbol, plot, problems.

\section{INTRODUCTION}

The implementation of a comprehensive approach to the aesthetic education of students in NUS involves, along with the traditional teaching of disciplines, their integration, in particular within the 
humanitarian, artistic cycle. Therefore, the problem of taking into account interdisciplinary and interdisciplinary links within modern school education is relevant. The Ministry of Education and Science has developed a "Concept of artistic and aesthetic education of students in secondary schools", which states that the integrative focus of the program aims to form a holistic picture of the world, and the personal developmental function of education suggests that instead of "the traditional "analysis" of works of art it is necessary to introduce into the scientific and pedagogical circulation and school practice the concept of "interpretation" of works of art" [see 11]. It is this approach that takes into account the interrelationships of different arts, develops critical thinking and creativity. To implement the above concept, a "Comprehensive program of artistic and aesthetic education in secondary and outof-school institutions" will be used. In lessons and extracurricular activities, students receive information about the environment, natural phenomena and processes that take place in it. Using the senses (vision, taste, smell, and touch), children learn the laws of nature, learn to adapt to environmental conditions, to live in harmony with the world around them. In the process of learning and education there is an awareness of the problems of sustainable development. The school program provides both scientific and rational, and aesthetic and emotional understanding of the essence of the phenomena of the surrounding reality. The concept of "landscape" is interdisciplinary and is widely used in various fields of art - pictorial, musical, poetic. Literary critics point out that the introduction of landscape elements in works of art affects the plot-compositional organization of the text, serves as an additional means of characterization, reflects the inner experiences of the characters, outlines the place and time of events [see 12], so it needs proper analysis and study. O. Bandura, L. Kalachaev, M. Leontiev, V. Lesin, V. Sorokin, L. Timofeev believe that landscapes are best analyzed as extra-plot elements, and M. Kurginyan, V. Vinogradov, O. Illinskaya, V. Kozhinov consider landscape as a plot component. Features of artistic landscapes depend on the manner of writing of the author, the genre features of the work. Rubrics such as "World of Nature" (5th grade) and "Me in the World" (6th grade) in the course of Ukrainian literature indicate the need for comprehensive formation of student competencies, the relationship of literature, fine arts, science, geography, etc. Visual materials, artistic illustrations, and musical accompaniment help to develop students' associative thinking, teach to analyze relationships and interactions, and synthesize information. The humanitarian component helps the child gain certain knowledge about the peculiarities of the environment, the relationship between people and nature, influences the formation of moral and aesthetic feelings.

\section{THEORETICAL BACKGROUND}

Our goal is to analyze the artistic functions of landscapes in children's stories "Christmas Tree" by Mykhailo Kotsiubynskyi and "Pine Tree" by Olena Pchilka and their aesthetic influence on a reader. To do this, it is necessary to perform a number of tasks: to characterize the poetics of the titles, the symbolism of the images, to explore the genre, plot and compositional features of these works, the means of characterization. Although the creative work of Mykhailo Kotsiubynskyi and Olena Pchilka has repeatedly become the object of scientific research by N. Antipchuk, N. Gaevska, A. Hulyak, I. Denysiuk, O. Zabolotny, N. Kalenichenko, Y. Kuznetsov, O. Kutsevol, S. Mykhida, P. Odarchenko, O. Pavlyshyn, O. Shevchenko, however, the functions of landscapes in these children's stories have not been the subject of a separate analysis. All this determines the relevance of our research; the consistency of names, topics, and issues creates the basis for the analysis of these works in a comparative manner.

\section{RESULTS AND DISCUSSION}

Critics point out that there was a shortage of children's reading in Ukrainian literature in the 19th century. Olena Pchilka tried to fill this gap with Ukrainian translations by such well-known authors as G. Andersen, C. Dickens, S. Lagerlof, R. Kipling, D. Swift, and others and their own works. Olena Pchilka's artistic output consists of works of various genres - poetry, stories, fables, plays. Trying to educate conscious citizens, the writer published Ukrainian-language magazines "Native Land", 
"Young Ukraine", which in addition to works of art contained interesting information about the nature of the native land - flora and fauna, natural phenomena, landscapes. "Young Ukraine" contained a corresponding section - "World Studies". Olena Pchilka pointed to the lack of literature for children, which prompted her to write: “... when I wanted to add a more appropriate story, or a poem, or a story from the world, or a fairy tale, or a joke, or something else, I sat down and wrote it myself - sometimes signing his name or position, and sometimes not" [quoted in 8, 267]. The writer claimed that, unfortunately, children's literature is not given due attention, namely, it influences the formation of the younger generation. Mykhailo Kotsiubynskyi pointed to the same problem. In his letter to P. Tychyna in 1912, he sadly stated: "We have, for example, very weak literature for children..." [5, vol. 6, p. 351]. This is what prompted the writer to create literature for children, including both lyrical and prose works.

The stories of "Pine Tree" by Olena Pchilka and Mykhailo Kotsiubynskyi's "Christmas Tree", first of all, attract attention with the echoes of the titles, which are associated with winter holidays and activate certain spatial and temporal dimensions in the reader's mind. V. Malyna points out that in Ukrainian culture the tree has become an attribute, "with which the stages of the calendar year, life cycle, economic activity, etc. are reproduced" [7, p. 227]. In folklore, the mythology of the tree is endowed with certain features, they can become national symbols. Landscapes are usually tied to a specific area, season.

The titles of the stories "Christmas Tree" and "Pine Tree", associated with the winter season, generate in the reader certain expectations, which are generally characteristic of the so-called Christmas stories. This genre is associated with the name of Charles Dickens, who under the title "Christmas Books" combines fascinating stories about holiday miracles. Such works help to immerse oneself in the world of childhood, to think about such philosophical categories as love, belief in a miracle. Christmas stories are found in the works of G. Andersen ("Christmas tree", "Girl with Matches"), F. Dostoevsky ("The Boy with Christ on the Christmas Tree"), M. Leskov ("The Depicted Angel", "Christ Visiting a Man"), P. Khlebnikov ("Christmas Gift"), Selma Lagerlef ("Christmas Guest", "Legends of Christ", "Holy Night"), M. Gogol ("The Night Before Christmas"), P. Myrnyi ("Morozenko"). Over time, writers increasingly moved away from mysticism, and talked about the amazing adventures that happened on the eve of the New Year and other winter holidays. I. Denysiuk noted that of all Ukrainian writers, Olena Pchilka cultivated the genre of so-called "Christmas" or "holiday stories" the most [2, p. 105]. Such works as "Funny Evening", "Chad", "Masquerade", “Three Christmas Trees" are a few examples.

The events take place at Christmas time in the stories "Pine Tree" by Olena Pchilka and Mykhailo Kotsiubynskyi's "Christmas Tree". The main characters of these works are Ivas and Vasylko, who grew up in poor peasant families. Olena Pchilka and Mykhailo Kotsiubynskyi do not ignore social issues, which indicates the realism of the image. The writers construct the plot in such a way that readers learn about the process of preparation for Christmas in the mansions and peasant homes. Teachers should choose pictures to illustrate the story. Contrast is the main artistic tool that helps readers immerse themselves in the reality of that time. Lords' families decorate Christmas trees, celebrate, buy presents, and poor families celebrate quite modestly. In both works, the symbolic marker of wealth/poverty is a Christmas tree/pine tree. Ivasyk and Vasylko's parents sell coniferous trees to buy boots from the shoemaker for the money raised. Vasylko's father is forced to cut down a Christmas tree, which he once gave to his son because his teacher praised him. The tree became a symbolic manifestation of love and recognition of the boy's achievements. Nature in both stories is described as an environment that forms a sense of freedom and beauty in children, "The forest was so beautiful, even in winter it did not seem sad, because there were a lot of pines between the black forests, and they always delight the eye with their evergreen attire" [9, p. 80]. The Christmas tree pleased Vasylko even when the bitter cold came and nature froze. When describing a Christmas tree and a pine tree, both Olena Pchilka and Mykhailo Kotsiubynskyi use diminutive and affectionate words: small, slender, round. In this way, writers influence the emotional perception of the work by readers. Although Vasylko "felt sorry for the slender Christmas tree, which alone amused the garden in winter" [5, vol. 1, p. 81], but he is aware of the needs of the family. It is this episode that helps to reveal the character of a boy who is kind, sensitive, 
responsible, obedient. Parents love their children very much, but, unfortunately, they cannot please them with beautiful toys or gifts. Names of the main characters are also presented in a loving form Ivas, Vasylko. The authors emphasize the age of the main characters, show their own commitment to them. In poor families, children are taught to work, to help their parents. Vasylko from M. Kotsiubynskyi's story "Christmas Tree" notices that his father is sad and understands "that there is no money to buy my mother's boots from a shoemaker?" [5, vol. 1, p. 80]. The boy wants to help his parents, but when he hears an offer from another man to buy his Christmas tree, he cannot contain his emotions. Vasylko and the tree together experience feelings of fear and pity. When the father picked up the ax, the boy "almost cried with pity" [5, vol. 1, p. 81]. The boy is grieving the loss of his favorite tree, which was cut down for the lord's pleasure. The creative style of Olena Pchilka and M. Kotsiubynskyi is characterized by the image of nature as a living being that feels, understands, is afraid: "As he approached, he swung his ax and struck the trunk. The tree trembled from the bottom to the top, as if frightened by an unexpected disaster, and a few green glitches fell on the snow. Yakym chopped, and the Christmas tree trembled, as in a sledgehammer. It seemed to Vasylko that it was about to groan. Just then the tree bent, crunched and, pulled up, fell on the snow..." [5, vol. 1, p. 81]. When his father carried the felled Christmas tree, Vasylko stopped. He couldn't hold back his tears, he covered the remaining stump with snow. This artistic detail conveys the feeling of emptiness, both spatial and internal, caused by the loss of a tree. Olena Pchilka and Mykhailo Kotsiubynskyi, through specific landscape details, raise issues that go beyond the work and are projected onto modern society. Trees, which remain "alive" even in winter, are the embodiment of natural beauty and grandeur. Pine tree from Olena Pchilka's work even flaunts her appearance and considers herself the best, special: "Oh, what a good thing, as someone of noble birth! There is nothing in the world like us, pines! Oh, my world, how beautiful I am..." [9, p. 81]. Once in the lord's chambers, the festively dressed pine tree does not even imagine what its future will be. Describing trees, the writers talk about them as beings who are able to feel, experience. For example, the statements of the pine tree in the story of the same name by Olena Pchilka are presented in the first person. That is why some researchers call this work fairy tale [3, p. 101 ], however, in our opinion, the reception of personification should not be interpreted as a fairy-tale plot because this genre has a number of features, including traditional beginnings and endings, allegorical images, spatiotemporal shifts. Olena Pchilka and Mykhailo Kotsiubynskyi do not give up the realism of the image. The "Christmas Tree" describes the adventures of a boy who had to take a tree to the manor. The history of the pine tree in Olena Pchilka's work of the same name is described much more widely than in the story by Mykhailo Kotsiubynskyi. The writer constructs the plot in such a way that the tree is not simply sold to the lords, but Ivas gets into the chambers twice: first, when he brings the tree and watches it being decorated; later the boy becomes a footman. Having visited the New Year's holiday for the first time, Ivasyk witnessed how the Christmas tree was thrown away, because the next day it became unnecessary. The boy feels sorry when he remembers this tree in the forest. The writer resorts to a contrasting image: "like a star in the sky" / "hat" [9, p. 83, 84]. To entertain the younger brothers and sister, Ivas takes the pine tree home. The writer exposes the consumer attitude towards nature. Using the example of this episode, we can analyze the environmental problem that is relevant in modern society.

In both stories, the winter element serves as a kind of test for the main characters: "Mete... Oh, my God, where is that road? Only... Ivanko got lost on the road! He rushes to one side or the other, tears well up in his eyes, because he can't do anything!" [9, p. 87]. The danger was previously pointed out by artistic details: in Mykhailo Kotsiubynskyi's "Christmas Tree" the image of a black crow on white snow, the cry of a magpie in Olena Pchilka's "Pine Tree". Descriptions of winter landscapes and blizzards exacerbate tragic premonitions. Musical accompaniment can help to feel the inner state of the main characters who are undergoing series of tests. The emotionality of the descriptions are emphasized by the brokenness of the phrases, the accumulation of exclamatory and interrogative constructions. To increase the feeling of horror and evoke sympathy, Mykhailo Kotsiubynskyi introduces scary landscapes of the night winter forest in the story. All events are described by writers through the feelings of the main characters. In "Christmas Tree" the forest seems "dead" to Vasylko. 
The imagination of a frightened child paints terrible pictures, "He looked around: healthy truncated oaks stood in the woods like shelters, and stretched dense black branches to him. It seemed to Vasylko that the dead, wrapped in a white veil, were reaching out to him..." [5, p . 84]. In the most difficult moments, the boy remembers his native house, his parents: "A blizzard was howling around, a cold wind was blowing and it was snowing, and Vasylko remembered a warm, clear father's house" [5, vol. 1, p. 83]. He managed to escape from the wolves, overcome all the dangers that awaited him in the woods, and return home.

In Olena Pchilka's "Pine Tree", a tree that the lords threw away as useless helped Ivas find his way home. The fate of Ivas is symbolically combined with the fate of a pine tree. First the tree, and then the boy found themselves in a rich family. However, lords need them only to fulfill their whims. The Christmas tree, which decorated the wards, was thrown away the next day. Olena Pchilka describes in detail the feelings that a tree experiences when it is placed near a firewood. Luxurious pine tree became a lords' pastime for one evening. The writer not only tells readers the New Year's story, but presents events from different angles, focusing on the experiences of the boy and the pine: "Yesterday she was so majestic, and now?.. Ivas looked - but he was sorry. He didn't know that this often happens to people!" [9, p. 84]. Later, a felled pine tree will save the life of a frightened child, who will run away from the lords' wards due to humiliation and ridicule: One word, for the pusher in all" $[9, \mathrm{p} .86]$. The marker of the new role was a russified version of the name Ivas - "Vanka". Being in the service of lords is so unbearable for a boy that he runs away unnoticed, because the sense of dignity is not measured by material wealth. Olena Pchilka proves that in a poor house you can be happier than in the mansions. Returning to his family in the village was a kind of salvation for Ivas. It is no coincidence that the protagonist is described in the bosom of nature. The boy quickly forgets the insults and returns to normal life. Vasylko also talks about his adventures in the woods without feeling afraid. Such happy endings are typical of Christmas stories.

\section{CONCLUSIONS}

Describing certain states of the characters, writers usually use the appropriate types of landscapes. Landscape consonance indicates a harmonious coexistence with nature, landscape dissonance helps to identify confrontations and conflicts. At the same time, landscapes help to characterize not only specific heroes, but society as a whole. In this way, the issues of works are projected on a much broader level. In the prose works by Olena Pchilka and Mykhailo Kotsiubynskyi, landscapes are closely connected with other artistic elements, so only a comprehensive analysis can reveal their functions. Landscapes mark space, outline the time and place of events, intertwine in the plot-compositional outline of works, influence the course of events, consistent with the psychological states of the characters. Through the introduction of landscape elements in works of art, the writers describe the close relationship between people and nature, raise environmental questions, and form a caring attitude towards the environment. By resorting to the synthesis of arts, using visual materials, and musical accompaniment, teachers can develop students' associative thinking and teach them to comprehensively analyze information. Analyzing the stories "Christmas Tree" by Mykhailo Kotsiubynskyi and "Pine Tree" by Olena Pchilka, students comprehend not only the themes and issues of works, but also comprehend the processes of human interaction with nature, which serves to form a humane attitude to the environment, develops aesthetic feelings. 


\section{REFERENCES}

[1] Antipchuk N. Olena Pchilka and the development of children's literature. Philological studies. Literary Studies, 4 (2004), 277-281. (in Ukrainian)

[2] Denisyuk I. Prose "of small forms" by Olena Pchilka. Ukrainian literary criticism, 10 (1970), 102-108. (in Ukrainian)

[3] Duck T. Olena Pchilka. Ukrainian literature for children and youth. Academy, Kyiv, 2016. (in Ukrainian)

[4] Kleimenova T. The inner world of the child in the stories of M. Kotsiubynskyi. Current problems of Slavic philology. Series: Linguistics and Literary Studies: Interuniversity. zb. Science. Art, XXI (2009), 173-180. (in Ukrainian)

[5] Kotsiubynskyi M. Works in 6 vols, Vol.1, Vol.6. Ed. Academy of Sciences of the Ukrainian SSR, Kyiv, 1961-1962. (in Ukrainian)

[6] Kuznetsov Y. The phenomenon of artistic detail. Psychology and society, 3 (69) (2017), 7-29. (in Ukrainian)

[7] Malyna V. The world tree and the ecumenical cross are related images of the creative spirit. Art History of Ukraine, 9 (2008), 223-239. (Ukrainian)

[8] Novakivska L. "Young Ukraine" by Olena Pchilka and her views on the problems of children's reading. Actual problems of Slavic philology: collection. Science. Art. XX (2009), 266-273. Available at: http://dspace.nbuv.gov.ua/bitstream/handle/123456789/16573/30-Novakivska.pdf?sequence=1. ～(in Ukrainian)

[9] Olena Pchilka. Educational work. Manuscripts Department of the Institute of Literature of the National Academy of Sciences of Ukraine. Fund 28, unit 191. (in Ukrainian)

[10] Pchilka O. Pine tree. Shkola, Kyiv, 2007. (Ukrainian)

[11] On approval of the Concept of artistic and aesthetic education of students in secondary schools and the Comprehensive program of artistic and aesthetic education ... Legislation of Ukraine. Document v1_11290-04, current version. Adoption of February 25, 2004. Available at: https://zakon.rada.gov.ua/rada/show/v1_11290-04\#Text. (in Ukrainian)

[12] Sebina E. Landscape. In: Chernets L.V. (Ed.) Introduction to Literary Studies. Literary work: basic concepts and terms: Textbook. Higher. sc., Academy, Moscow, 1999. Available at: http://taviak.ru/distance/wp-content/uploads/2014/obshcheobrazovatelnye_distsipliny/Literatura/ Chernec.pdf. (in Russian)

Address: Nataliia Vivcharyk, Vasyl Stefanyk Precarpathian National University, 57 Shevchenko St., Ivano-Frankivsk 76018, Ukraine.

E-mail: vivcharik@ukr.net.

Received: 02.02.2021; revised: 18.03.2021.

Вівчарик Наталія. Пейзаж та його функції в оповіданнях Михайла Коцюбинського “Ялинка" та Олени Пчілки “Сосонка". Журнал Прикарпатського університету імені Василя Стефаника, 8 (1) (2021), 148-154.

У статті доведено, що реалізація комплексного підходу до естетичного виховання учнів в НУШ передбачає поряд із традиційним викладанням дисциплін їх інтеграцію, зокрема в рамках гуманітарного, мистецького циклу. “Концепція художньо-естетичного виховання учнів у загальноосвітніх навчальних закладах" вказує на потребу врахування міжпредметних, міжгалузевих зв'язків у межах сучасної шкільної освіти, адже навчально-виховні процеси забезпечують як раціональне, так і естетично-емоційне осмислення явищ навколишньої дійсності. У статті звернуто увагу на те, що поняття пейзаж є міждисциплінариним і використовується в різних сферах 
мистецтва, зокрема дітературі, яка впливає на формування особистості, допомагає отримати певні знання про особливості навколишнього середовища, взаємоз'язки людини і природи. Детально проаналізовано функції пейзажів у дитячих оповіданнях Михайла Коцюбинського “Ялинка" і Олени Пчілки "Сосонка". Звернуто увагу на сугодосність назв художніх творів. Доведено, що титди імпліцитно окреслюють час дії, проектуються на сюжет. Для творчої манери Олени Пчілки та М. Коцюбинського властиве “оживлення” природи. На фоні зимових пейзажів письменники відображають життя різних верств населення, звичаї та традиції, пов'язані з Різдвом. Вказано, що пейзажі виконують як зображальну, так і характеродогічну функцію. Описуючи підготовку до Різдва, письменники вдаються до використання контрастів, що допомагае оприявнити соціальну проблематику. У обох творах символічним маркером багатства/бідності виступає ядинка/сосонка. Описи зимової стихії викдикають трагічні передчуття. Емоційність розповіді підкреслює обірваність фраз, накопичення окличних та питальних конструкцій. Доведено, що пейзажі передають внутрішні переживання героїв, які щасливо проходять усі випробування і повертаються додому. Вдаючись до синтезу мистецтв, використовуючи наочні матеріали, музичний супровід, вчителі можуть розвивати асоціативне мислення учнів, вчити комплексно аналізувати інформацію. Аналізуючи оповідання Михайла Коцюбинського “Ялинка" та Олени Пчілки “Сосонка", учні розглядають не тільки тематику та проблематику, а осмислюють процеси взаємодії дюдини з природою, що служить формуванню гуманного ставлення до навкодишнього середовища, розвиває естетичні почуття.

Ключові слова: виховання, учні, інтеграція, синтез мистецтв, художня література, пейзаж, оповідання, заголовок, образ, деталь, пейзаж, контраст, символ, сюжет, проблематика. 